九州大学学術情報リポジトリ

Kyushu University Institutional Repository

\title{
CERAMBYCIDAE OF KUROSHIMA ISLAND, WITH DESCRIPTIONS OF TWO NEW SPECIES AND TWO NEW SUBSPECIES (COLEOPTERA)
}

Makihara, Hiroshi

https://doi.org/10.5109/2369

出版情報 : ESAKIA. 10，pp.45-69，1977-02-15. Hikosan biological laboratory， Faculty of Agriculture, Kyushu University バージョン：

権利関係 : 


\title{
CERAMBYCIDAE OF KUROSHIMA ISLAND, WITH DESCRIPTIONS OF TWO NEW SPECIES AND TWO NEW SUBSPECIES (COLEOPTERA)*
}

\author{
Hiroshi Makihara \\ Entomological Laboratory, Faculty of Agriculture, Kyushu University, \\ Fukuoka 812, Japan
}

Synopsis Cerambycidae of Kuroshima Is., Kagoshima Prefecture, are reported for the first time. Thirty-two species are known to occur on that island. Two new species Palausybratokaraensis and Acalolepta nigricornis, and two new subspecies Acalolepta luxuriosa kuro and Rhodopina tokarensis obscura are described.

This paper reports the Cerambycidae of Kuroshima Is., Kagoshima Prefecture, for the first time, based on the collection made by me in July 23-25, 1975, in addition to a few specimens collected by Mr. N. Senda in 1967. Thirty-two species including 2 new species and 2 new subspecies are recognized.

The Kuroshima Is. is located in southwest of Satsuma Peninsular about $50 \mathrm{~km}$ from the Cape of Bo-no-Saki, and about $50 \mathrm{~km}$ northwest of Kuchinoerabujima Is., and is included in the Tokara group. It is an old volcanic island geologically distinct from Koshiki Is. and Yakushima Is. This island, with $15.2 \mathrm{~km}$ in circumference and a total area of about 36 square $\mathrm{km}$, is rather mountainous, and the highest peak reaches $622 \mathrm{~m}$ above the sea level. This island is densely covered by Castanopsis sieboldii which is the dominant tree species there.

I wish to express my sincere gratitude to Professor Y. Hirashima and Associate Professor K. Yano of Kyushu University for their continuous guidans. My thanks are due to Dr. M. Hayashi of Osaka Jonan

* Contribution from the Entomological Laboratory, Faculty of Agriculture, Kyushu University, Fukuoka (Ser. 3, No. 35). 
Women's Junior College, Associate Professor S. Azuma of Ryukyu University, Associate Professor M. Sato of Nagoya Women's College, Mr. N. Ohbayashi of Kanagawa Horticultural Experiment Station, and Messrs. K. Komiya, M. Takakuwa, J. Okuma and N. Senda who offered valuable specimens for my present study.

\section{Subfamily Prioninae \\ Tribe EURYPODINI}

1. Megopis (Aegosoma) sinica (White) (Fig. 2)

Aegosoma sinicum White, 1853, Cat. Col. Brit. Mus. 7: 30.

Megopis (Aegosoma) sinica : Lameere, 1909, Ann. Soc. Ent. Belg. 53: 138.

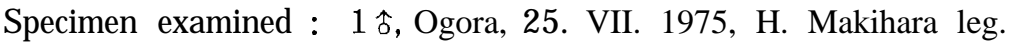
Distribution: Hokkaido, Honshu, Shikoku, Kyushu, Izu Isls., Yakushima Is., Kuroshima Is., Kuchinoerabujima Is., Nakanoshima Is., Amami-Oshima Is. and Okinawa Is.; Taiwan and China.

Note: New record. This example was collected in a hole of the decayed part of a cut down tree trunk of Zanthoxylumailantoides S. et Z., Rutaceae at night.

\section{Subfamily Aseminae \\ Tribe ASEMINI}

2. Cephalallus unicolor (Gahan) (Fig. 3)

Criocephalus unicolor Gahan, 1906, Fauna Brit. Ind. Col. 1: 97.

Criocephalus (Cephalallus) oberturi subsp. unicolor : Mitono, 1940, Cat. Col. Jap. 8: 79.

Arhopalus (Cephalallus) unicolor: Gressitt, 1951, Longicornia 2 : 37.

Cephalallus unicolor: Ohbayashi, 1963, Ins. Jap. color nat. edita 2: 269.

Specimens examined : 2 占占, Og̉ora, 24. VII. 1975, H. Makihara

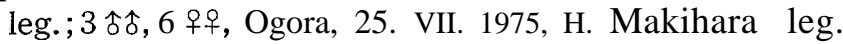

Distribution : Honshu, Shikoku, Kyushu, Izu Isls., Tsushima Is., Tanegashima Is., Yakushima Is., Kuroshima Is., Amami-Oshima Is., Okinawa Is. and Minami-Daito Is.; Korea, Taiwan, C. China, Burma, Assam and Laos.

Note: New record. These examples were collected on a cut down tree trunk of Pinus thunbergi i Parl., Pinaceae at night. 


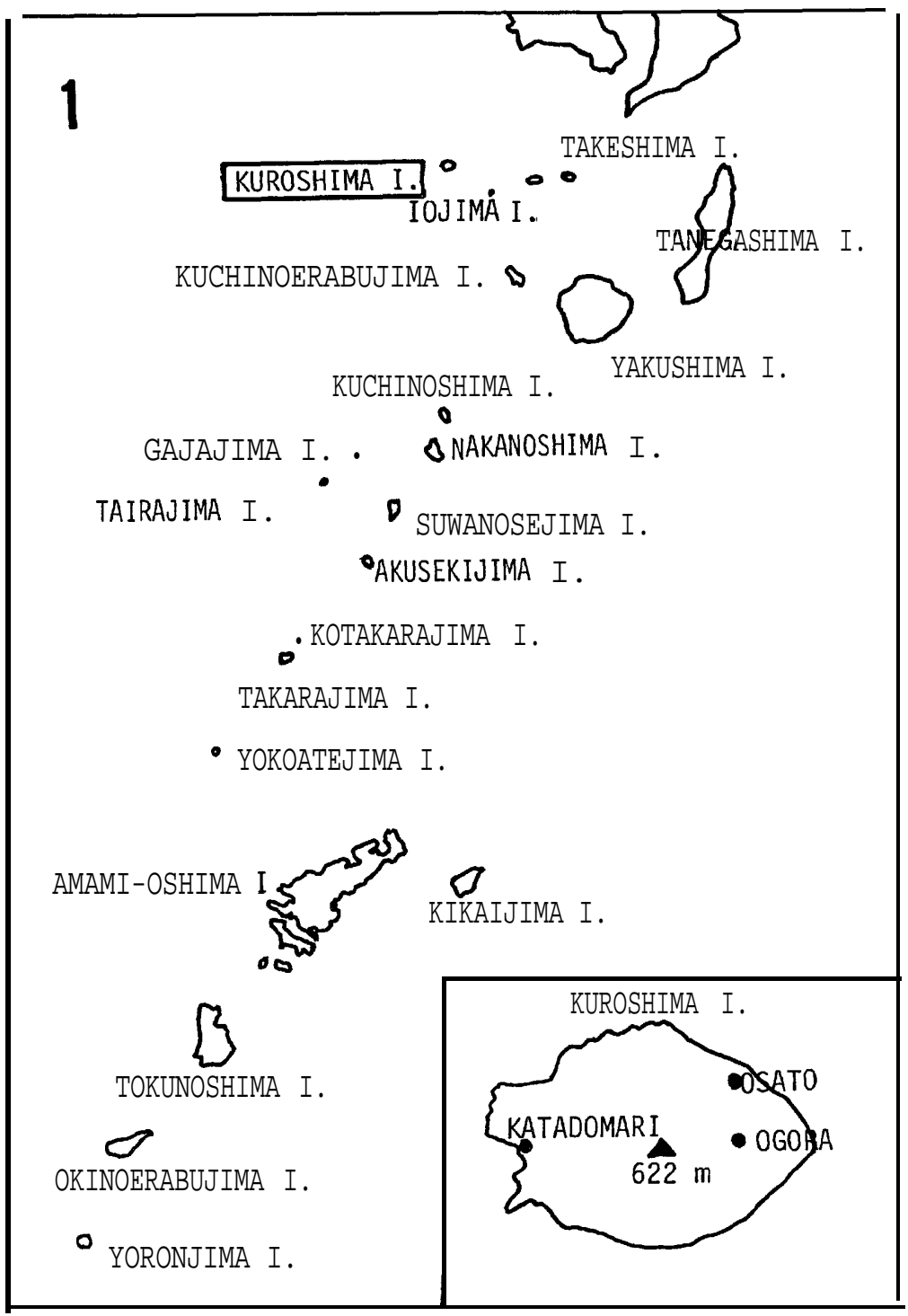

Fig. 1. A map of Kuroshima Island and neighbours. 


\section{Subfamily Cerambycinae \\ Tribe CERAMBYCINI}

3. Margites fulvidus (Pascoe) (Fig. 4)

Cerambyx fulvidus Pascoe, 1858, Trans. Ent. Soc. Lond. (2) 4: 236.

Pachydissus (?) fulvidus : Bates, 1873, Ann. Mag. Nat. Hist. (4) 12: 152.

Margites fulvidus : Gahan, 1891, Ann. Mag. Nat. Hist. (6) 7: 26.

Specimen examined : 1 우, Ogora, 25. VII. 1975, H. Makihara leg. Distribution : Honshu, Shikoku, Kyushu, Tsushima Is., Tanegashima Is., Yakushima Is., Kuroshima Is., Nakanoshima Is., AmamiOshima Is. and Okinawa Is.; Taiwan and China.

Note: New record. This example was collected on a cut down tree trunk of Castanopsis sieboldii (Mak.), Fagaceae at night.

\section{Tribe PHORACANTHINI}

4. Allotraeus (Nysia) rufescens (Pic) (Fig. 7)

Pseudoallotraeus rufescens Pic, 1923, Mél. Exot. Ent. 38: 13.

Allotraeus (Nysia) rufescens: Hayashi, 1955, Col. illust. Ins. Jap. 2: 153.

Specimens examined : 1令, 1 ㅇ, Ogora, 23. VII. 1975, H. Makihara leg.; 2 战, 3 qㅇ․, Ogora, 24. VII. 1975, H. Makihara leg.; 7 沾, 3 우우, Ogora, 25. VII. 1975, H. Makihara leg.

Distribution : Honshu, Shikoku, Kyushu, Tanegashima Is., Yakushima Is., Takeshima Is.* and Kuroshima Is.

Note: New record. These examples were collected on a cut down tree trunk of Castanopsis sieboldii (Mak.), Fagaceae and at light.

\section{Tribe Callidiopinj}

5. Ceresium holophaeum Bates

Ceresium holophaeum Bates, 1873, Ann. Mag. Nat. Hist. (4) 12: 153.

Specimens examined : 6 $\hat{\circ}, 7$ 우, Ogora, 23. VII. 1975, H. Makihara leg.; 14 令令, 15 우우, Ogora, 24. VII. 1975, H. Makihara leg. ; 15 占占, 18 우우, Ogora, 25. VII. H. Makihara leg.

Distribution: Hokkaido, Honshu, Shikoku, Kyushu, Izu Isls., Tsushima Is., Koshiki Is., Tanegashima Is., Yakushima Is., Kuroshima Is., Kuchinoerabujima Is., Kuchinoshima Is., Nakanoshima Is.,

*1우 Takeshima Is., 29. V. 1973, H. Makihara leg. (New record). 
Amami-Oshima Is., Tokunoshima Is. and Okinawa Is.

Note: New record. These examples were collected on a cut down tree trunk of Castanopsis sieboldii (Mak.), Fagaceae, on flowers of Lilium longiflorum Thumb, Liliaceae and at light. All the specimens of this species from Kuroshima Is. are darkish, and are recognized as the forma yuasai.

6. Ceresium sinicum White

Ceresium sinicum White, 1855, Cat. Col. Brit. Mus. 8: 245.

Specimen examined : $1 \hat{\delta}$, Ogora, 24. VII. 1975, H. Makihara leg. D istribution : Honshu, Kyushu and Kuroshima Is. ; Taiwan, China, Hainan Is., Tonkin and Thailand.

Note: New record. This examples is hesitantly identified as C. sinicum.

7. Ceresium fuscum Matsumura et Matsushita

Ceresium fuscum Matsumura et Matsushita, 1932, Ins. Matsu. 7 (1/2): 67.

Specimens examined : $1 \hat{o}$, Ogora, 23. VII. 1975, H. Makihara leg. ; 4 占占, 7 우우, Ogora, 24. VII. 1975, H. Makihara leg.; 2 ôf, 10 우우, Ogora, 25. VII. 1975, H. Makihara leg.

D istribution : Kyushu, Kanmurijima Is., Okinoshima Is. (Kochi Pref.), Okinoshima Is. (Fukuoka Pref.), Izu Isls., Koshiki Is., Tanegashima Is., Yakushima Is., Kuroshima Is., Kuchinoerabujima Is., Kuchinoshima Is., Nakanoshima Is., Takarajima Is., Kikaijima Is., Amami-Oshima Is., Tokunoshima Is., Okinoerabujima Is., Okinawa Is., Miyako Is., Tarama Is., Ishigaki Is,, Iriomote Is., Hateruma Is. and Yonaguni Is.

N ote : New record. These examples were collected on a cut down tree trunk of Castanopsis sieboldii (Mak.), Fagaceae and at light. Body colour of all the specimens from Kuroshima Is. is dark brownish black.

\section{Ceresium simile Gahan (Fig. 5)}

Ceresium simile Gahan, 1890, Ann. Mag. Nat. Hist. (6) 5: 169.

Specimens examined : 1 , Ogora, 23. VII. 1975, H. Makihara leg. ; 2 ôf, 1우, Osato, 23. VII. 1975, H. Makihara leg.; 1\}, 2 웅, Ogora, 24. VII. 1975, H. Makihara leg. ; 4 sิ占, 14 우우, Ogora, 25. VII. 1975, H. Makihara leg.

Distribution : Honshu, Shikoku, Kyushu, Kanmurijima Is., Izu IsIs., Bonin Is., Okinoshima Is. (Fukuoka Pref.), Yakushima Is., 
Kuroshima Is., Kuchinoerabujima Is., Kuchinoshima Is., Nakanoshima Is., Takarajima Is., Yokoatejima Is., Amami-Oshima Is., Tokunoshima Is., Okinawa Is., Miyako Is.?, Ishigaki Is. ? and Iriomote Is. ?

Note: New record. These examples were collected on a cut down tree trunk of Castanopsis sieboldii (Mak.), Fagaceae, on floweres of Liliumlongiflorum Thumb., Liliaceae and at light.

\section{Tribe OBRIINI}

9. Stenhomalus taiwanus Matsushita

Stenhomalus taiwanus Matsushita, 1933, Jour. Fac. Agr. Hokkaido Imp. Univ. 34: 307.

Specimens examined : 1 占, 2 우우, Ogora, 23. VII. 1975, H. Makihara leg.; 4 송ㅅㅇ, 3 우우, Ogora, 24. VII. 1975, H. Makihara leg.; 3 ิํㅇ, 11 우오, Ogora, 25. VII. 1975, H. Makihara leg.

Distribution: Hokkaido, Honshu, Shikoku, Kyushu, Izu Isls., Tsushima Is., Tanegashima Is., Yakushima Is., Kuroshima Is., Kuchinoerabujima Is,, Okinawa Is., Miyako Is., Ishigaki Is., Iriomote Is.* and Hateruma Is.

Note: New record. These examples were collected on a cut down tree trunk of Zanthoxylum ailantoides S. et Z., Rutaceae.

\section{Tribe THRANINI}

10. Thranius variegatus Bates (Fig. 6)

Thraniusvariegatus Bates, 1873, Ann. Mag. Nat. Hist. (4) 12: 196.

Specimen examined : 1 우, Ogora, 23. VII. 1975, H. Makihara leg. Distribution : Hokkaido, Honshu, Shikoku, Kyushu, Kanmurijima Is., Izu Isls., Tsushima Is., Yakushima Is., Kuroshima Is. and Nakanoshima Is.

Note: New record.

\section{Tribe Clytini}

11. Chlorophorus quinquefasciatus (Castelnau et Gory)

Clytus quinquefasciatus Castelnau et Gory, 1841, Hist. Nat. Icon. Ins. Col. : 101.

\footnotetext{
*1 1 , Mitara, Iriomote Is., 19. VIII, 1971, S. Azuma leg. (New record).
} 
Chlorophorus quinquefasciatus : Kano, 1927, Trans. Nat. Hist. Soc. Formosa 17: 67.

Specimens examined : $\mathbf{6} \hat{\jmath}\}, 6$ 우, Ogora, 23. VII. 1975, H. Makihara leg. ;1 1,1 우, Ogora, 24. VII. 1975, H. Makihara leg. ; 2 呫, 2 우우, Ogora, 25. VII. 1975, H. Makihara leg.

Distribution: Honshu, Shikoku, Kyushu, Izu Isls., Okinoshima Is. (Shikoku), Tsushima Is., Koshikijima Is., * Yakushima Is., Kuroshima Is., Tanegashima Is., Kuchinoerabujima Is., Kuchinoshima Is., Nakanoshima Is., Takarajima Is., Kikaijima Is., AmamiOshima Is., Tokunoshima Is., Okinoerabujima Is., Okinawa Is., Miyako Is., Ishigaki Is., Iriomote Is. and Yonaguni Is. ; Korea.

Note: New record. Most of examples were collected on a cut down tree trunk of Castanopsis sieboldii (Mak.), Fagaceae in the daytime, and some were collected at night.

\section{Chlorophorus muscosus (Bates)}

Clytanthus muscosus Bates, 1873, Ann. Mag. Nat. Hist. (4) 12: 198.

Chlorophorus muscosus: Matsushita, 1933, Jour. Fac. Agr. Hokkaido Imp. Univ. 34 (2): 284.

Specimens examined : $1 \uparrow, 6$ 우, Ogora, 23. VII. 1975, H. Makihara leg.; 1ㅅ․, Ogora, 24. VII. 1975, H. Makihara leg.; 1 o, 4 우우, Ogora, 25. VII. 1975, H. Makihara leg.

Distribution: Honshu, Shikoku, Kyushu, Izu Isls., Okinoshima Is. (Fukuoka Pref.), Tsushima Is., Koshikijima Is., ** Tanegashima Is., Yakushima Is., Kuroshima Is., Amami-Oshima Is., Tokunoshima Is., Okinoerabujima Is. and Okinawa Is.

Note: New record. These examples were collected on a cut down tree trunk of Castanopsis sieboldii (Mak.), Fagaceae in the daytime.

\section{Subfamily Lamiinae \\ Tribe Mesosini}

13. Mesosa (A phelocnemia) longipennis Bates (Fig. 11)

Mesosalongipennis Bates, 1873, Ann. Mag. Nat. Hist. (4) 12: 313.

\footnotetext{
* 1今, Teuchi, Shimokoshikijima Is., 6. VIII. 1975, H. Makihara leg. (New record).

** 1 今, Teuchi, Shimokoshikijima Is., 6. VIII. 1975, H. Makihara leg. (New record).
} 
Mesosa (Aphelocnemia) longipennis : Hayashi, 1955, Col. illust. Ins. Japan 2: 172 .

Specimens examined : 4 䑙, 4 우우, Ogora, 23. VII. 1975, H. Makihara leg.; 5 战, 7 우우, Ogora, 24. VII. 1975, H. Makihara leg.; 16 呫, 14 우오, Ogora, 25. VII. 1975, H. Makihara leg.

Distribution: Hokkaido, Honshu, Shikoku, Kyushu, Oki Is., Izu Isls., Tanegashima Is., Yakushima Is., Kuroshima Is. and Kuchinoerabujima Is. ; Korea.

Note: New record. These examples were collected on a cut down tree trunk of Castanopsis sieboldii(Mak.), Fagaceae.

\section{Tribe Homonoeini}

14. Bumetopia japonica (Thomson) (Figs. 8, 9)

Yochostyla japonica Thomson, 1868, Physis, 2: 151.

Bumetopia oscitans : Matsushita, 1933, Jour. Fac. Agr. Hokkaido Imp. Univ. 34 (2): 355.

Bumelopia oscitans var. variegata : Matsushita, 1933, Jour. Fac. Agr. Hokkaido Imp. Univ. 34 (2): 355.

Bumetopia japonica: Hayashi, 1955, Col. illust. Ins. Japan 2: 174.

Specimens examined : 2 oิㅅ, 5 우오, Osato, 23. VII. 1975, H. Makihara leg.; $6 \$ 8,10$ q워, Osato, 24. VII. 1975, H. Makihara leg.; $2 \hat{o}\}$, 2 우우, Osato, 25. VII. 1975, H. Makihara leg.

Distribution : Honshu (Yamaguchi Pref.), Kyushu, Tsushima Is., Koshikijima Is., Tanegashima Is., Yakushima Is., Takeshima Is.,* Kuroshima Is. and Kuchinoerabujima Is.

Note: New record. These examples were collected on Pleioblastuslinearis (Hack.), Gramineae. Female of this species from this island is specially large in size. It is interesting that this genus shows a special feature of geographic variation, the detail of which will be published in a separate paper.

\section{Tribe APOMECYNINI}

15. Sybra ordinata tokara Hayashi (Fig. 31)

Sybra punctatostriata : Hayashi, 1956, Bull. Osaka Mun. Mus. Nat. Hist. 9: 17.

Sybra loochooana: Hayashi, 1956, Bull. Osaka Mun. Mus. Nat. Hist. 9: 21.

* 1今, Takeshima Is., 29. V. 1973, H. Makihara leg. (New record). 
Sybra ordinata tokara Hayashi, 1972, Ent. Rev. Japan 24 (1/2): 33.

Specimens examined : 3 웅, Osato, 23. VII. 1975, H. Makihara leg. ;2占占, 4 우우, Osato, 24. VII. 1975, H. Makihara leg. ;1占, Osato, 25. VII. 1975, H. Makihara leg.

Distribution : Kuroshima Is., Kuchinoerabujima Is., Kuchinoshima Is., Nakanoshima Is. and Takarajima Is.

Note: New record. These examples were collected on a decayed tree trunk of Ficus sperba (Miq.) var. japonica Miq., Moraceae.

16. Sybra baculina nipponensis Hayashi (Fig. 30)

Sybra posticalis baculina: Hayashi, 1956, Bull. Osaka Mun. Mus. Nat. Hist. 9: 17, 22.

Sybra baculina: Ohbayashi, 1963, Icon. Ins. Japon col. nat. edita 2: 311.

Sybra baculina nipponensis Hayashi, 1972, Ent. Rev. Japan 24 (1/2): 32.

Specimens examined : 4 战, 3 우우, Osato, 23. VII. 1975, H. Makihara leg.; 5 呫, 16 웅, Osato, 24. VII. 1975, H. Makihara leg.; 1\}, 4 우, Osato, 25. VII. 1975, H. Makihara leg.

Distribution : Shikoku, Kyushu, Okinoshima Is. (Shikoku), Koshikijima Is., Tanegashima Is., Yakushima Is., Kuroshima Is., Kuchinoerabujima Is., Kuchinoshima Is., Nakanoshima Is. and Takarajima Is.

Note : New record. These examples were collected on decayed tree trunks of Ficus sperba (Miy.) var. japonica Miq., I;. sarmentosa Roxb. var. nipponica (Fr. et Sav.) and Morusaustralis Poir, Moraceae. The former and this species also show remarkable geographic and individual variations, and the determination of the subspecific status is difficult.

\section{Palausybra tokaraensis Makihara, sp. nov. (Figs. 27, 28)}

Body reddish brown ; blackish brown on prothorax, triangular part in middle of, small triangular one of apical half and apical part of elytra, and scutellum ; dark reddish brown on vertex; reddish brown part of elytra (particularly longitudinal keels), tibiae, tarsi, and median and lateral sides of prothorax covered with long yellowish brown pubescence ; sparse short yellowish brown pubescence on head, femora and ventral side of body; sparse short dark brown pubescence on prothorax and blackish brown part of elytra.

Female : Body oval, broadest in middle of elytra; head deeply and not very closely punctured; frons convex, about 1.4 times as long as broad; median furrow shallow and vertex triangularly concave ; eyes 
coarsely facetted, inferior eye lobe three-fourths as long as gena. Antennae six-sevenths as long as body, relative length of each segment is as follows: $4.0: 1.7: 6.8: 6.0: 3.8: 3.5: 3.2: 3.0: 2.9: 2.5: 3.0$.

Prothorax subcylindrical, broadest in middle, six-sevenths as long as broad, weakly and roundly expanded at sides, coarsely punctured ; medioanterior portion of prothorax broadly and distinctly convex.

Scutellum small, oblong and rounded at apex.

Elytra very thickened, very oval, about 1.7 times as long as broad (9.8: 5.7), twice as long as head and prothorax combined, not much broader basally than prothorax, widest in middle, rounded at apex; disc of elytra with three developed longitudinal keels, roughly and closely punctured on interspaces, the second raised at middle and the third relatively weak.

Hind wing reduced.

Legs short; femora rather clavate; claws small.

Metasternum and lateral sides of venter of abdomen deeply punctured ; relative length of abdominal segments from 4 to 7 is as follows : 1.3: 1.0: 0.9: 1.8. ; apex of 7 weakly rounded.

Length : $7.6 \mathrm{~mm}$, width : $2.9 \mathrm{~mm}$, thickness (height of elytra) : $2.3 \mathrm{~mm}$.

Male: Body wholly dark; reddish brown part of elytra smaller; body more slender, elongated oval ; median furrow indistinct and vertex very weakly triangularly concave ; antennae as long as body, the relative length of each segment is as follows : $1.6: 0.5: 2.8: 1.5: 1.5: 1.3: 1.2$ : 1.2: $1.0: 1.2$.

Elytra thickened and oval, the ratio of width to length as in female.

Legs rather short.

Relative length of abdominal segments, in ventral view, from 4 to 7 is as follows : 1.0: 0.8: $0.6: 1.3$; apex of 7 transeverselly truncated.

Length : $5.7 \mathrm{~mm}$, width : $2.2 \mathrm{~mm}$, thickness : $1.8 \mathrm{~mm}$.

Holotype : + (Type No. 2065, Kyushu University), Ogora, Kuroshima Is., Kagoshima Pref., 25. VII. 1975, H. Makihara leg.; paratype : $1 \hat{\jmath}$, Nakanoshima Is., Tokara Isls., 14. VII. 1974, T. Seino leg.

Note: This new species is closely related to $P$. hachijoensis Hayashi from the Izu Islands (Hachijo Is. and Mikura Is.), but differs from it in the following points: Body strongly oval and more thickened, antennae are shorter, and the apex of elytra is rounded.

This new species was treated under the genus Palausybra at present, but this and hachijoensis differ from Palausybra in having the following points: Body oval ; vertex triangularly concave ; prothorax concave at base and shorter; elytra thickened, convex at middle, deeply punctured 


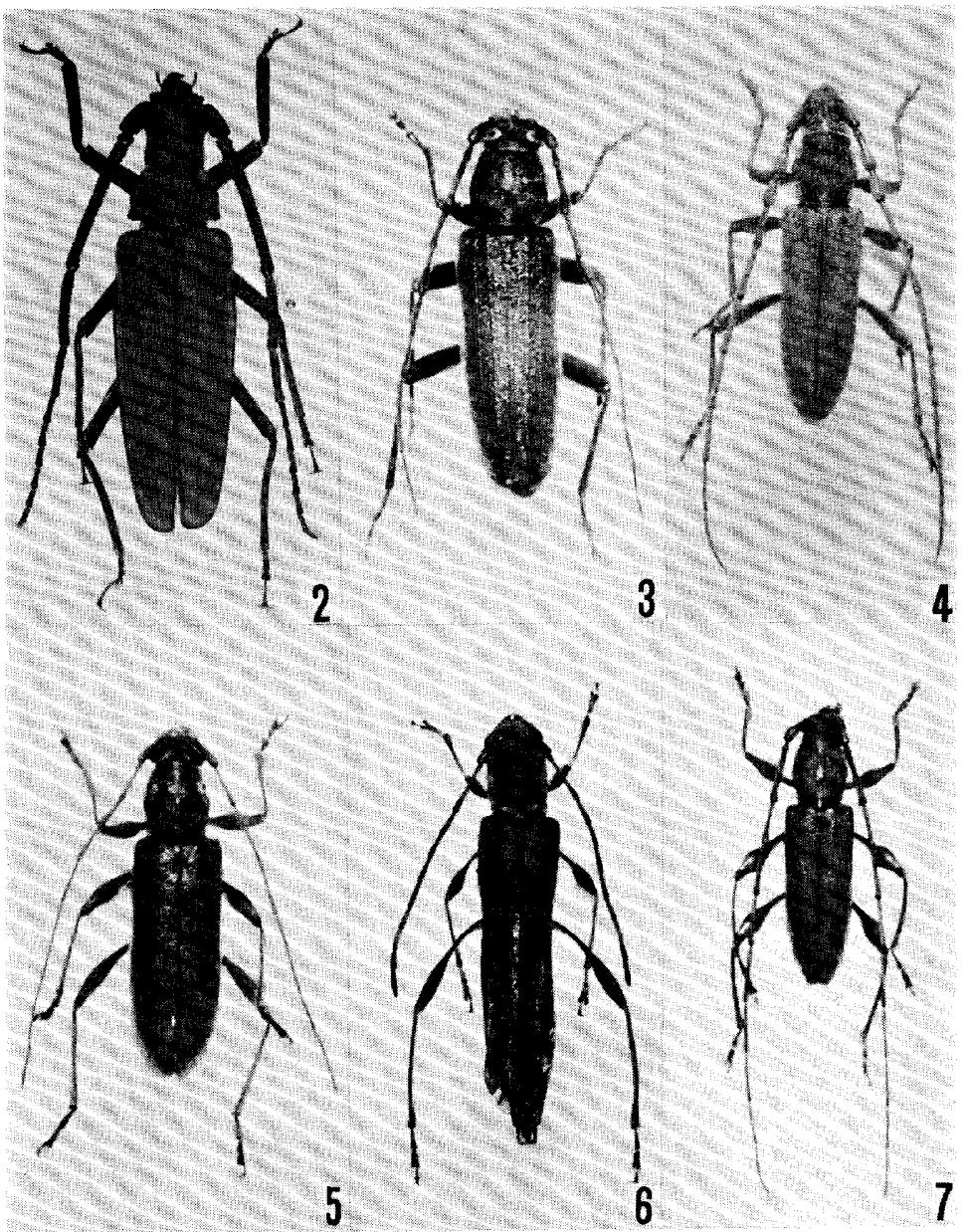

Fig. 2. Megopis (Aegosonza) sinica (White).

Fig. 3. Cephalallus unicolor (Gahan).

Fig. 4. Margites fulvidus (Pascoe).

Fig. 5. Ceresium simile Gahan.

Fig. 6. Thranius variegatus Bates.

Fig. 7. Allotraeus (Nysia) rufescens(Pic). 


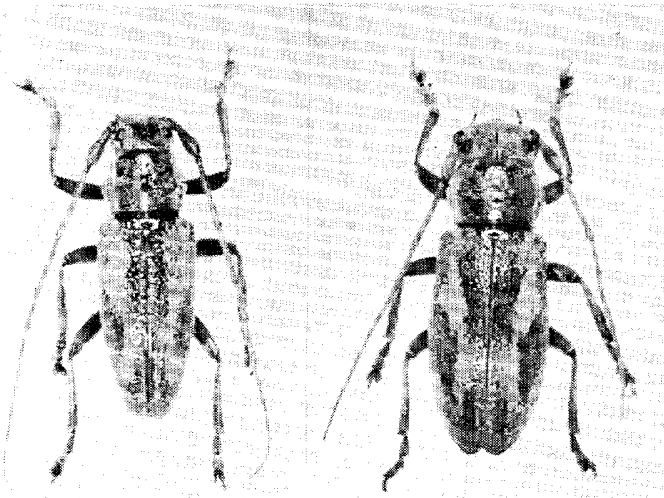

8

9
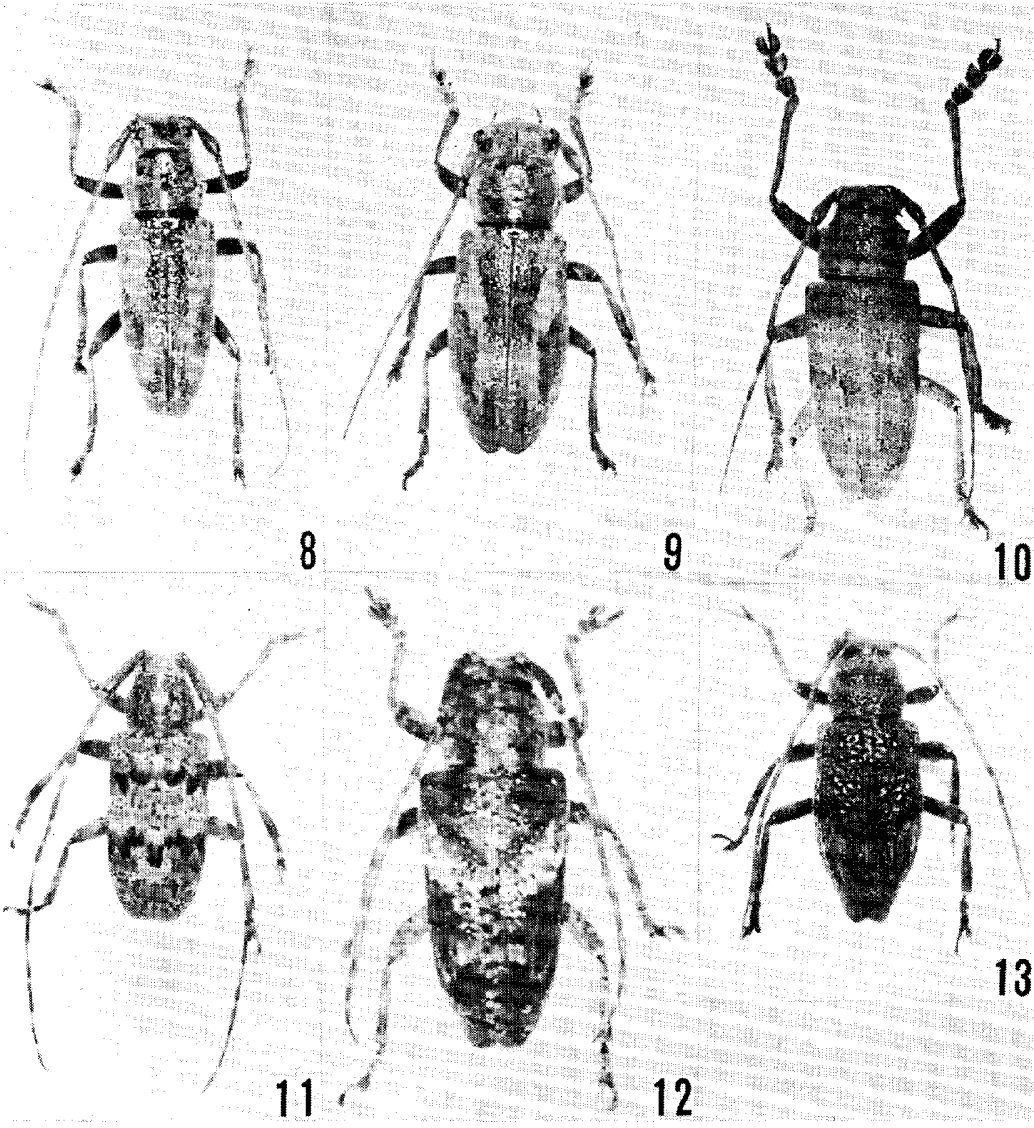

10

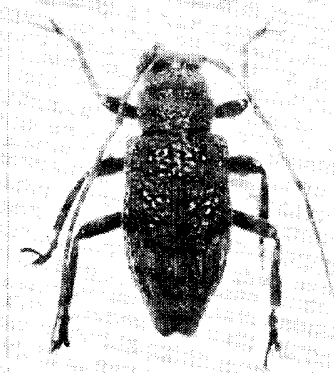

13

Fig. 8. Bumetopia japonica (Thomson), male.

Fig. 9. Ditto, female.

Fig. 10. Abryna coenosa Newman.

Fig. 11. Mesosa (Aphelocnemia) longipennis Bates.

Fig. 12. Pterolophia gibbosipennis subcristipennis Breuning et Ohbayashi.

Fig. 13. Pseudale obovata Hayashi. 


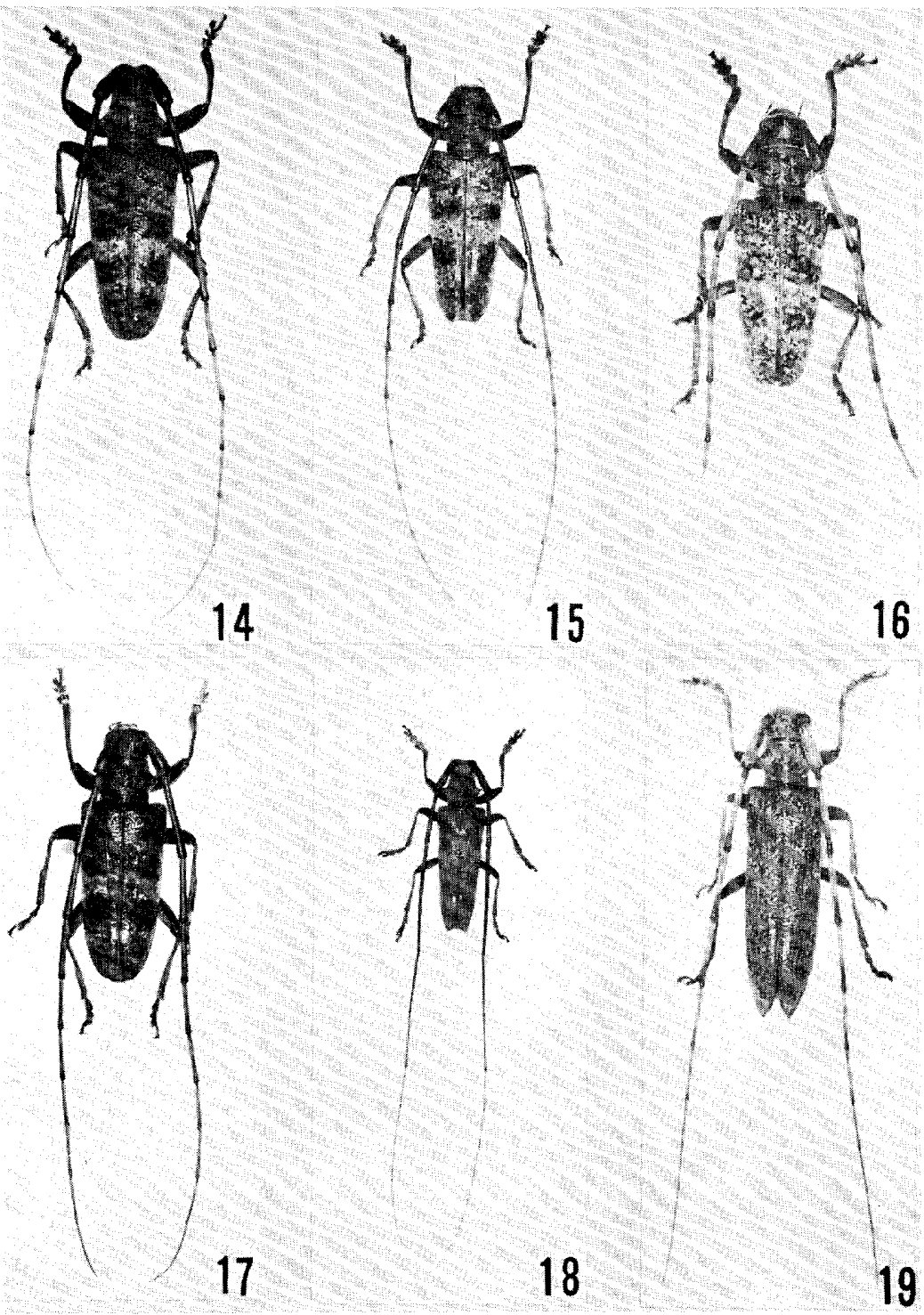

Fig. 14. Acalolepta Iuxuriosa (Bates), male from Fukuoka Pref.

Fig. 15. Ditto, male from Yakushima Island.

Fig. 16. Acalolepta luxuriosa kuniyoshii Hayashi, male from Okinawa Island.

Fig. 17. Acalolepta luxuriosa kuro Makihara, subsp. nov., male.

Fig. 18. Uraecha gilva Yokoyama, male. Fig. 19. Ditto, female. 


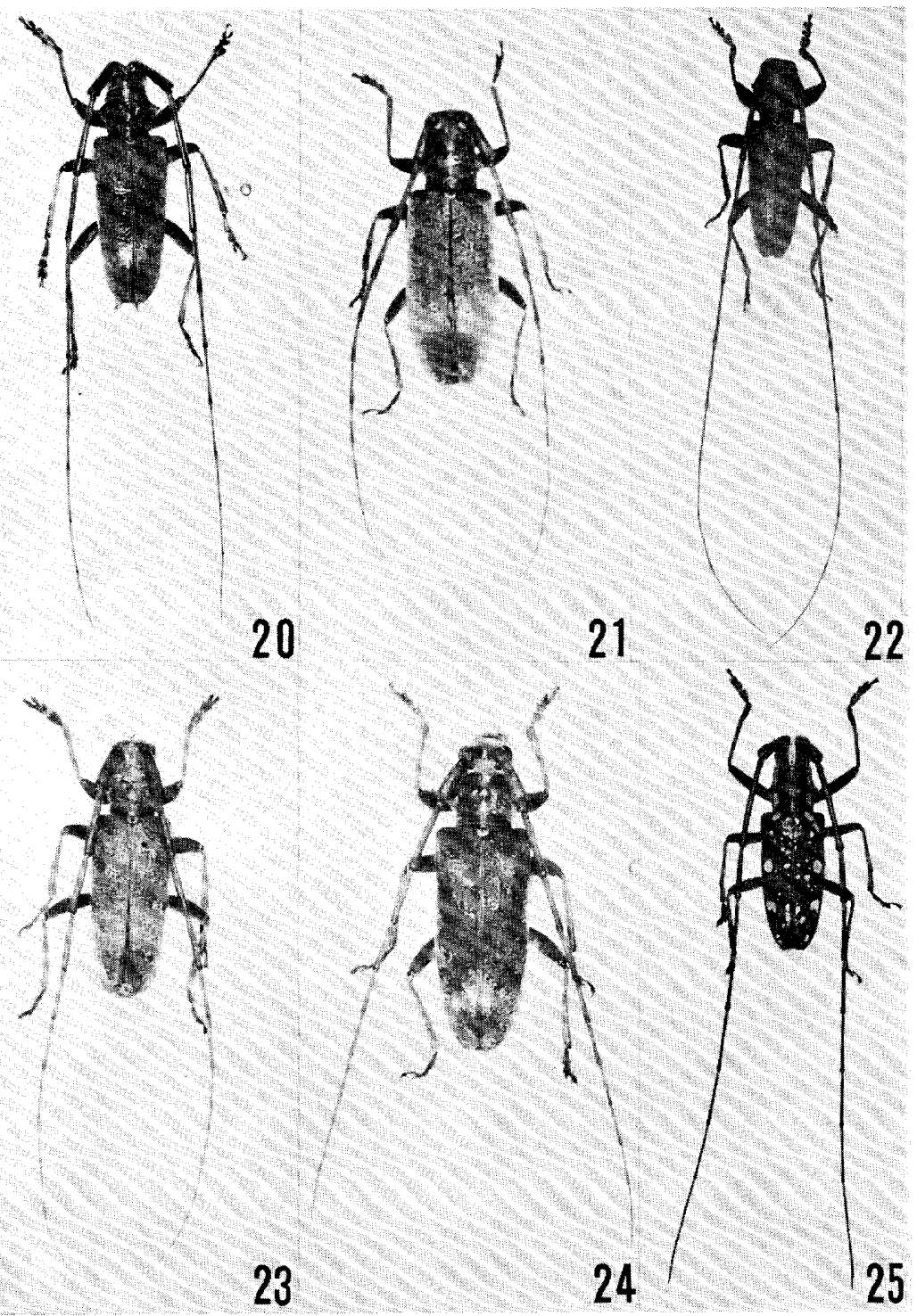

Fig. 20. Acalolepta nigricornis Makihara, sp. nov., male.

Fig. 21. Ditto, female.

Fig. 22. Acalolepta hamai (Hayashi).

Fig. 23. Acalolepta fraudatorix yakushimana Hayashi, male from Yakushima Island.

Fig. 24. Ditto, female from Yakushima Island.

Fig. 25. Psacothea hilarisinsularis Hayashi. 


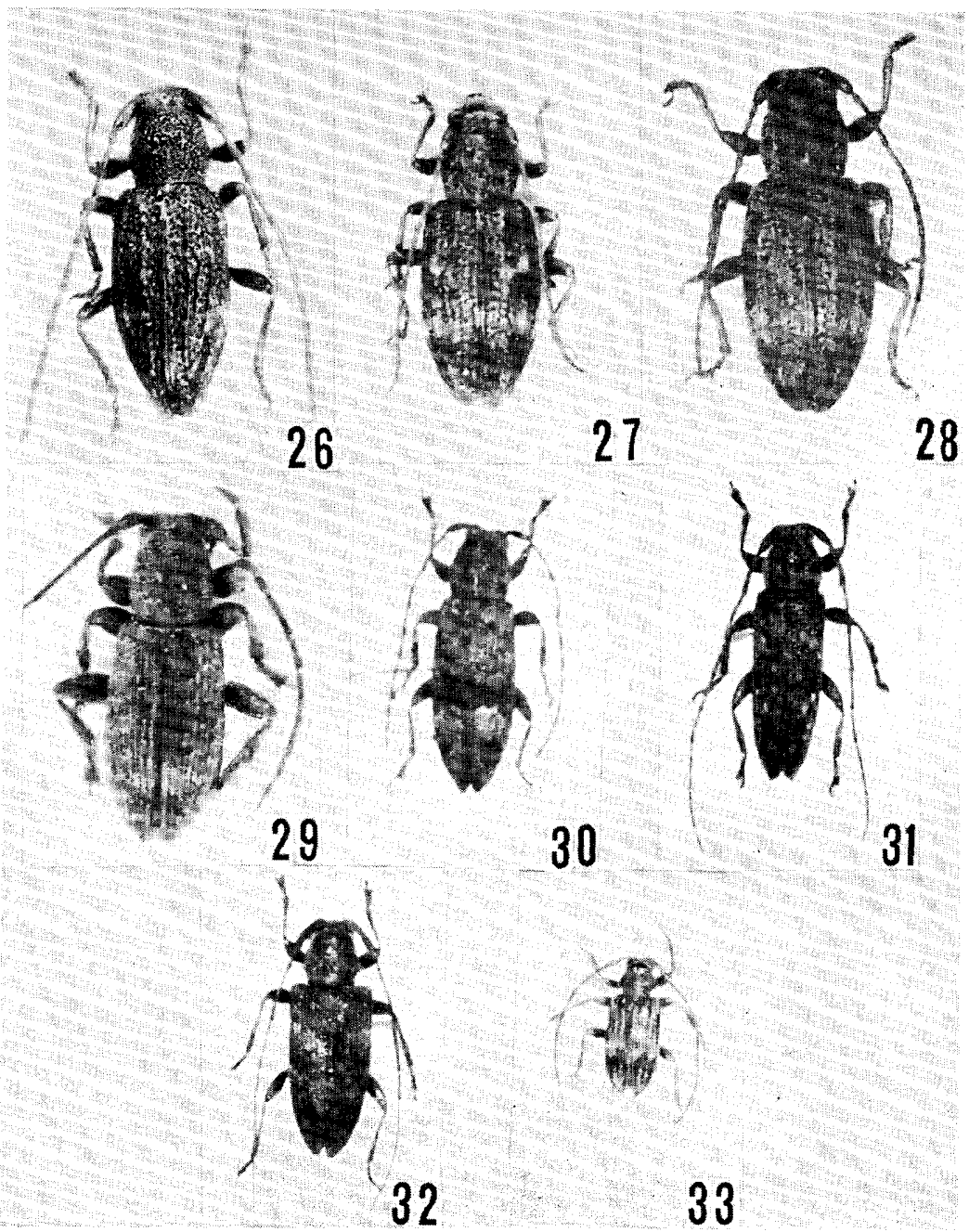

Fig. 26. Palausybra hachijoensis Hayashi, male from Mikurajima Island,

Fig. 27. Palausybra tokaraensis Makihara, sp. nov., male from Nakanoshima Island.

Fig. 28. Ditto, female from Kuroshima Island.

Fig. 29. Palausybra chibi Hayashi, female from Botel-Tobago, paratype.

Fig. 30. Sybra baculina nipponensis Hayashi.

Fig. 31. Sybra ordinata tokara Hayashi.

Fig. 32. Estoliops fasciatus fasciatus Matsushita.

Fig. 33. Exocentrus lineatus lineatus Bates. 


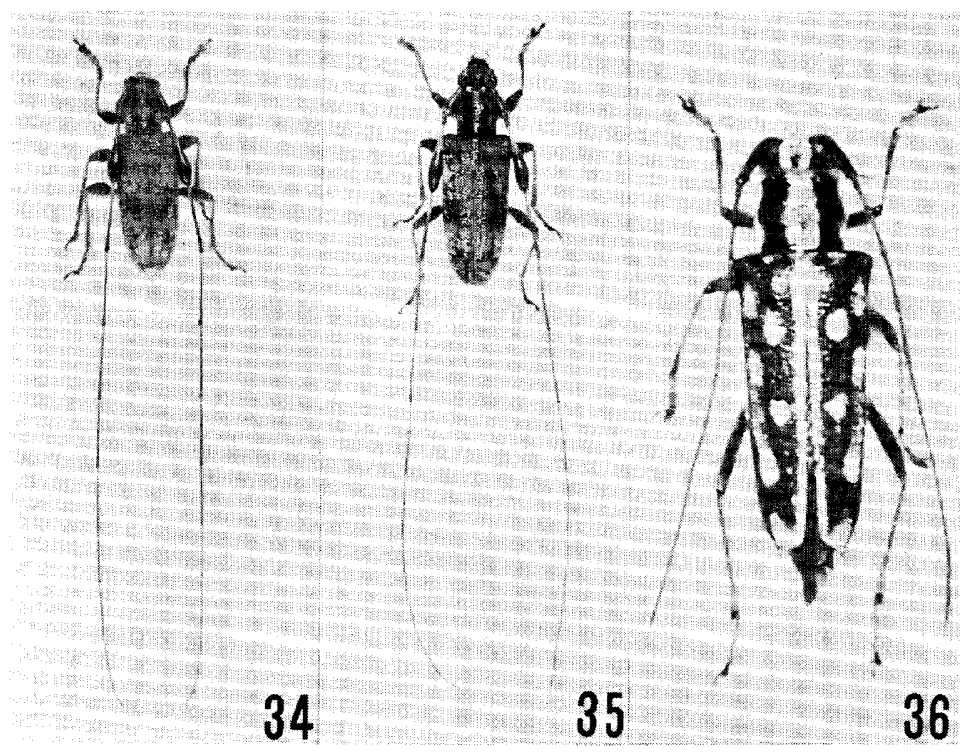

Fig. 34. Rhodopina tokarensis obscura Makihara, subsp. nov., male.

Fig. 35. Rhodopina tokarensis tokarensis Hayashi, male from Nakanoshima Island.

Fig. 36. Glenea (Glenea) chlorospila Gahan.

and with three strong keels; and shape of mesosternal process, trapezoid. I think these two species are to be separated from Palausybra. The holotype female was collected on a cut down tree trunk of Castanopsis sieboldii (Mak.), Fagaceae at night.

\section{Tribe Pteroplini}

18. Abryna coenosa Newman (Fig. 10)

Abryna coenosa Newman, 1842, Entomologist 1: 289.

Abryna obscura Schwarzer, 1925, Ent. Blätt. 21: 65.

Abryna coenosa Zoochooana Matsushita, 1933, Ins. Matsu. 7: 108.

Palimna obscura oshimensis Breuning, 1955, Bull. Soc. Ent. Fr. 60: 64.

Abryna obscura uniformis Breuning et Ohbayashi, 1966, Bull. Japan Ent. Ac. 2 (6): 32.

Specimens examined : 4 令令, 3 우우, Osato, 23. VII. 1975, H. Makihara leg. ; 6 오, 9 우우, Osato, 24. VII. 1975, H. Makihara leg.; 3 战, 3 우오, Osato, 25. VII. 1975, H. Makihara leg. 
Distribution : Kyushu, Tanegashima Is., Yakushima Is., Kuroshima Is., Kuchinoerabujima Is., Kuchinoshima Is., Nakanoshima Is., Takarajima Is., Amami-Oshima Is., Tokunoshima Is., Okinoerabujima Is., Okinawa Is., Miyako Is., Ishigaki Is., Iriomote Is., Hateruma Is. and Yonaguni Is. ; Taiwan, China and Philippines. Note: New record. These examples were collected on a bamboo, Pleioblasius linearis (Hack.), Gramineae. This species is remarkable in geographic and individual variabilities, and many subspecific names have been proposed.

\section{Pterolophia annulata (Chevrolat)}

Coptops annulata Chevrolat, 1845, Rev. 2001. 8: 99.

Pronetha Bowringii Pascoe, 1865, Trans Ent. Soc. London (3) 3: 170.

Pterolophia annulata: Gahan, 1895, Ann. Mus. Civ. Genova 34: 69.

Pterolophia bowringii : Aurivillius, 1922, Col. Cat. 73: 253.

Pterolophia scutellata Schwarzer, 1925, Ent. Blätt. 21: 66.

Pterolophia annulicornis Pic, 1925, Bull. Soc. Ent. France: 138.

Specimens examined : 3 $\{\hat{\delta}, 2$ 우, Osato, 23. VII. 1975, H. Makihara leg.; 1 令, 1 ㅇ․, Osato, 24. VII. 1975, H. Makihara leg. ;1 ㅅ, 1 우, Osato, 25. VII. 1975, H. Makihara leg.

Distribution : Honshu, Shikoku, Kyushu, Izu Isls., Tsushima Is., Koshikijima Is., Tanegashima Is., Yakushima Is., Kuroshima Is., Kuchinoerabujima Is., Kuchinoshima Is., Nakanoshima Is., Takarajima Is., Kikaijima Is., Amami-Oshima Is., Tokunoshima Is., Okinoerabujima Is., Okinawa Is., Miyako Is., Tarama Is., Ishigaki Is., Iriomote Is., Hateruma Is., Irabu Is. and Yonaguni Is.; Korea, Taiwan, China, Hainan Is., Hong-Kong, Makao and Burma. Note: New record. These examples were collected on cut down tree trunks of Ficus sperba (Miq.) var. japonica Miq., F.sarmentosa Roxb. var. nipponica (Fr. et Sav.) and Morus australis Poir., Moraceae.

20. Pterolophia gibbosipennis subcristipennis Breuning et Ohbayashi (Fig. 12)

Pterolophia gibbosipennis: Hayashi, 1956, Bull. Osaka Mun. Mus. Nat. Hist. 9: 15.

Pterolophiasubcristipennis Breuning et Ohbayashi, 1964, Bull. Japan Ent. Ac. 1 (4): 16.

Pterolophia gibbosipennis subcristipennis : Hayashi, 1969, Ins. Life Japan 1: 112.

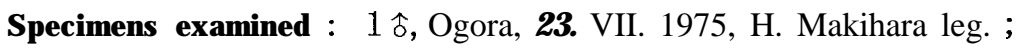


1今, Ogora, 24. VII. 1975, H. Makihara leg. ;1令,1우, Ogora, 25. VII. 1975, H. Makihara leg.

Distribution : Kuroshima Is., Yakushima Is., Kuchinoerabujima Is., Nakanoshima Is., Takarajima Is., Amami-Oshima Is. and Tokunoshima Is.

Note: New record. These examples were collected on a dead branch of Castanopsis sieboldii (Mak.), Fagaceae at night. This species also shows a remarkable geographic variation, and the subspecific name subcristipennis is applied for the species from Kuroshima Is. in this time.

21. Pseudale obovata Hayashi (Fig. 13)

Pterolophia camura: Hayashi, 1956, Bull. Osaka Mun. Mus. Nat. Hist. 9: 15.

Pterolophia bigibbera: Hayashi, 1969, Ins. Life Japan 1: 111.

Pseudale obovata Hayashi, 1971, Ent. Rev. Japan 23 (1): 12.

Specimens examided : 1今,2 우으, Ogora, 24. VII. 1975, H. Makihara leg. ; 3 소, 6 우우, Ogora, 25. VII. 1975, H. Makihara leg.

Distribution : Tsushima Is., Koshikijima Is., Yakushima Is., Kuroshima Is., Nakanoshima Is., Takarajima Is., Tokunoshima Is., Okinoerabujima Is. and Okinawa Is.

Note: New record. These examples were collected on a cut down tree trunk of Castanopsis sieboldii (Mak.), Fagaceae at night. This species is interesting in the feature of geographic variation and differentiation. An analysis of the variation and differentiation of local populations of this species is being made by me.

Tribe Agnini

22. Psacothea hilaris insularis Hayashi (Fig. 25)

Psacothea hilaris insularis Hayashi, 1960, Ent. Rev. Japan 11 (1): 25.

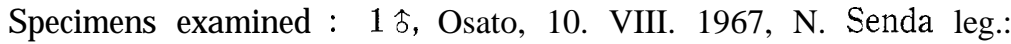
19, Katadomari, 22. VII. 1975, H. Makihara leg. ; 3 sf占, 1 우, Osato, 23. VII. 1975, H. Makihara leg.; 2 战, 6 우우, Ogora, 24. VII. 1975, H. Makihara leg. ; 1§, Osato, 25. VII. 1975, H. Makihara leg.

Distribution : Yakushima Is., Kuroshima Is. and Kuchinoerabujima Is.

Note: New record. These examples were collected on a living tree trunk of Morus australis Poir., Moraceae. This species occurs in East Asia, and is interesting in the feature of geographic variation and differentiation. An analysis of the vari- 
ation and differentiation of local populations of this species is also being made by me.

23. Uraecha gilva Yokoyama (Figs. 18, 19)

Uraecha gilva Yokoyama, 1966, Ent. Rev. Japan, 18 (2): 56.

Specimens examined : 1 ㅇ, Osato, 10. VIII. 1967, N. Senda leg. ; 1 , 3 우우, Osato, 23. VII. 1975, H. Makihara leg.; 1 \&, 1 우, Ogora, 23. VII. 1975, H. Makihara leg.; 2 §ł战 2 우, Osato, 24. VII. 1975, H. Makihara leg.; 1소, 2 우우, Osato, 25. VII. 1975, H. Makihara leg. ;1令, 2 우우, Ogora, 25. VII. 1975, H. Makihara leg.

Distribution : Kuroshima Is., Kuchinoerabujima Is. and Nakanoshima Is.

Note : New record. These examples were collected on cut down tree trunks of Ficus sperba (Miq.) var. japonica Miq., F.sarmentosa Roxb. var. nipponica (Fr. et Sav.), Moraceae Castanopsis sieboldii (Mak.), Fagaceae and Zanthoxylum ailanthoides S. et Z., Rutaceae and cut down plants of Rubus rosaefolius Smith ssp. maximowiczii Focke., Rosaceae in the daytime and at light.

24. Acalolepta hamai (Hayashi) (Fig. 22)

Cypriola sejuncta hamai Hayashi, 1962, Ent. Rev. Japan 14 (2): 36.

Acalolepta hamai: Hayashi, 1969, Ins. Life Japan 1: 132.

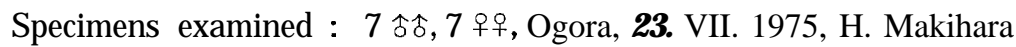
leg.; 25 $\{\hat{\delta}, 16$ 우우, Ogora, 24. VII. 1975, H. Makihara leg.; 53 §ิో人, 27 우오, Ogora, 25. VII. 1975, H. Makihara leg. ;1 $\hat{o}$, Ogora, 2325. VII. 1975, H. Makihara leg.

Distribution : Kuroshima Is., Kuchinoerabujima Is., Kuchinoshima Is. and Nakanoshima Is.

Note: New record. These examples were collected on cut down tree trunks of Zanthoxylum ailantoides S. et $Z$., Rutaceae and Castanopsis sieboldii (Mak.), Fagaceae in the daytime and at night, on cut down plants of Rubus rosaefolius Smith ssp. maximowiczii Focke., Rosaceae in the daytime, at light and by the Malaise trap. This species belongs to the sejuncta species group, and this group is remarkably variable in the geographic distribution. Application of the present specific name to the Kuroshima populations is rather questionable.

25. Acalolepta nigricornis Makihara, sp. nov. (Figs. 20, 21)

Body blackish brown; dark brown on antennae and legs; covered 
with dark chocolate brown, dense and short pubescence ; pubescence on head sometimes dark.

Frons sparsely punctured, with a median longitudinal furrow extending backward through triangularly concave vertex to occiput ; the ratio of length of inferior eye lobe to gena as follows : $2.9: 2.5$ (male), 2.8: 2.2 (female).

Antennae impunctate ; basal node of 1st segment covered with sparse, short, dark chocolate brown pubescence ; 1st \& 2nd segments with short dark chocolate brown pubescence, 3rd to 10th segments with short golden yellow pubescence except for each apex which is dark brown. Basal node of 1st antennal segment with regularly developed punctures; 1st dark brown and thickened in middle and at apex ; 2nd dark brown; 3rd brown except apex; 4th to 10th brown except bases and apices; apex of 3rd and bases and apices of 4th to 10th dark brown; 11th reddish brown; 3rd to 5th thickened and 6th to 11th slender ; antennae 2.66 times as long as body in male, 1.75 times in female ; relative length of each segment is as follows : 7.0: 1.0: 13.9: 11.4: $10.9: 10.0: 10.0: 9.8$ : 9.8 : 9.6: 17.0 (male), 16.2: 1.3: 26.6: 20.5 : 18. 0: 16.3: 16.3: 15.8: 15.6: $15.4: 23.9$ (female).

Prothorax clearly broader than long including lateral projections, narrowly and strongly constricted near base, narrowly and less strongly constricted near apex, and weakly and widely constricted near bases of lateral projections which are large and almost conical; disc of prothorax uneven and sinuated, with slightly raised portions which are impunctate.

Scutellum densely covered with long golden yellow pubescence, semicircular, and 1.5 times as broad as long.

Elytra broader than prothorax, about 2.1 times as long as broad in male, about 2.3 times as long as broad in female; broadest at base, gradually narrowed apically, weakly and obliquely truncate at apex, disc depressed at basal one-fourth to one-third, finely punctured, especially so on basal half.

Legs impunctate, covered with silver gray pubescence except apical halves of fore tibiae on ventral sides, of mid and hind tibiae on dorsal and ventral sides and tarsi on ventral sides, and these portions covered with golden brown hairs of uniform length.

Body impunctate ventrally ; ratio of 4 th to 7 th segments is as follows: $2.2: 1.8: 2.0: 3.0$ in male, $6.8: 5.1: 4.7: 13.0$ in female; 7 th sternite emarginate at apex.

Length : $20.8 \mathrm{~mm}$, width : $7.0 \mathrm{~mm}$ (male) ; length : 13.5-22.0 mm, width : 
4.5-7.0 mm (female).

Holotype: 占 (Type No. 2066, Kyushu University), Ogora, Kuroshima Is., Kagoshima Pref., 25. VII. 1975, H. Makihara leg. ; paratypes: 1 ㅇ, Osato, 8. VIII. 1967, N. Senda leg. ; 1 क, Ogora, 23. VIII. 1975, H. Makihara leg. ; 1 q, Ogora, 24. VII. 1975, H. Makihara leg.

Note: This new species belongs to the fraudatorix species group, and is closely related to $\mathbf{A}$. fraudatorix yakushimana Yokoyama of Yakushima Is. and $A$. mikurensis Hayashi of the Izu Islands (Hachijo Is. and Mikura Is.), but this is distinct in having the following characters : Body blackish brown; antennae dark brown, covered with dark chocolate brown pubescence ; basal node of 1st antennal segment sparsely covered with pubescence; and longer antennae (excluding the members of this group of the Ryukyus).

26. Acalolepta luxuriosa kuro Makihara, subsp. nov. (Fig. 17)

This new subspecies differs from A. Zuxuriosa Zuxuriosa (Bates) and A. Zuxuriosa kuniyoshii Hayashi in having the body covered with grayish white pubescence, and antennae dark reddish brown.

The pattern of geographic variation of Iuxuriosa from south Japan to Okinawa Is. (excluding the population on Kuroshima Is. and Nakanoshima Is,) is distinctive in being the pubescence on the body getting lighter in color from north to south. But the new subspecies from Kuroshima Is. and Nakanoshima Is. is the darkest.

Length : $26.4 \mathrm{~mm}$ (i4.4, max. 32.0, min. 20.0) in male; $23.3 \mathrm{~mm}( \pm 4.0$, max. 29.0, min. 20.0) in female.

Holotype: 令 (Type No. 2067, Kyushu University), Ogora, Kuroshima Is., Kagoshima Pref., 23. VII. 1975, H. Makihara leg. ; paratypes :1\}, Nakanoshima Is., Tokara Isls., 7. VII. 1974, J. Okuma leg. ; 2 占占, 2 우우, Ogora, 23. VII. 1975, H. Makihara leg.; 3 朎, Ogora, 24. VII. 1975, H. Makihara leg. ; 2 $\{, 1$ ㅇ, Ogora, 25. VII. 1975, H. Makihara leg.

Note: This new subspecies was collected on leaves of Fatsia japonica (Thunb.), Araliaceae. The new subspecific name, kuro, means black in Japanese.

\section{Tribe RHODOPININI}

27. Rhodopina tokarensis obscura Makihara, subsp. nov. (Fig. 34)

This new subspecies is very similar to $R$. orientalis Yokoyama of Kuchinoerabujima Is. and R. tokarensis tokarensis Hayashi of Nakanoshima Is., but it differs from them in having the following points : 
Body covered with longer yellowish brown pubescence; prothorax more hairy and with three obscure longitudinal fulvous stripes; and club of 3rd antennal segment shorter and broader.

Holotype : $\hat{o}$ (Type No. 2068, Kyushu University), Ogora, Kuroshima Is., Kagoshima Pref., 23. VII. 1975, H. Makihara leg. ; paratype: 우, Ogora, 24. VII. 1975, H. Makihara leg.

28. Sophronica obrioides (Bates)

Lasiapheles obrioides Bates, 1873, Ann. Mag. Nat. Hist. (4) 12: 382.

Sophronica obrioides : Hayashi, 1956, Bull. Osaka Mun. Mus. Nat. Hist. 9: 17.

Specimens examined : 1§, Osato, 23. VII. 1975, H. Makihara leg. ; 1 오, Osato, 24. VII. 1975, H. Makihara leg.; 2 우우, Ogora, 25. VII. 1975, H. Makihara leg.

Distribution: Honshu, Shikoku, Kyushu, Izu Isls., Tsushima Is., Koshikijima Is., Tanegashima Is., Yakushima Is., Kuroshima Is., Kuchinoerabujima Is., Nakanoshima Is., Amami-Oshima Is. and Tokunoshima Is.

Note: New record. These examples were collected on cut down tree trunks of Trachelospermum asiaticum var. liukiuensis (Hats.), Apocynaceae and Castanopsis sieboldii (Mak.), Fagaceae.

29. Mimectatina meridiana (Matsushita)

Doius meridianus Matsushita, 1933, Jour. Fac. Agr. Hokkaido Imp. Univ. 34: 380 .

Mimectatina meridiana: Hayashi, 196'2, Ent. Rev. Japan 14 (2): 38.

Specimens examined : 2 战, 6 우우, Osato, 23. VII. 1975, H. Makihara leg.; 3 战, 12 우우, Ogora, 24. VII. 1975, H. Makihara leg.; 4 우우, Ogora, 25. VII. 1975, H. Makihara leg.

Distribution : Shikoku, Kyushu, Izu Isls., Okinoshima Is. (Shikoku), Koshikijima Is., Tanegashima Is., Yalushima Is., Kuroshima Is., Kuchinoerabujima Is., Kuchinoshima Is., Nakanoshima Is., Takarajima Is., Kikaijima Is., Amami-Oshima Is., Tokunoshima Is., Okinoerabu jima Is., Okinawa Is., Miyako Is., Irabu Is., Tarama Is., Ishigaki Is., Iriomote Is., Hateruma Is. and Yonaguni Is.; Taiwan and Hawaii.

Note: New record. These examples were collected on cut down tree trunks of Castanopsis sieboldii (Mak.), Fagaceae, Ficus superba (Miq.) var. japonica Miq., Morusaustralis Poir., Moraceae, and Zanthoxylum ailantoides S. et Z., Rutaceae. 


\section{Tribe Acanthocinini}

30. Estoliops fasciatus fasciatus Matsushita (Fig. 32)

Estoliops fasciatus Matsushita, 1943, Trans, Nat. Hist. Soc. Taiwan 33 (242-243) : 575 .

Estoliops fasciatus fasciatus: Samuelson, 1965, Pac. Ins. 91: 123.

Specimens examined : 1\}, 4 우오, Ogora, 23. VII. 1975, H. Makihara leg. ;2古占, 1 ㅇ, Ogora, 24. VII. 1975, H. Makihara leg.

Distribution : Honshu, Shikoku, Kyushu, Tsushima Is., Koshikijima Is., Tanegashima Is., Yakushima Is., Kuroshima Is., Kuchinoerabujima Is. and Nakanoshima Is.

Note: New record. These examples were collected on a cut down tree trunk of Castanopsis sieboldii (Mak.), Fagaceae. The species group to which the present species belongs shows a remarkable geographic variation.

31. Exocentrus lineatus lineatus Bates (Fig. 33)

Exocentrus Zineatus Bates, 1873, Ann. Mag. Nat. Hist. (4) 12: 384.

Specimens examined : 2 战, 2 우, Ogora, 23. VII. 1975, H. Makihara leg. ; 2 우오, Ogora, 24. VII. 1975, H. Makihara leg.

Distribution : Honshu, Shikoku, Kyushu, Sado Is., Oki Is., Tsushima Is., Koshikijima Is., Tanegashima Is., Yakushima Is. and Kuroshima Is.

Note: New record. These examples were collected on a cut down tree trunk of Castanopsis sieboldii (Mak.), Fagaceae. The E. Zineatus species group also shows a remarkable geographic variation.

\section{Tribe Saperdini}

32. Glenea (Glenea) chlorospila Gahan (Fig. 36)

Glenea chlorospila Gahan, 1897, Ann. Mag. Nat. Hist. (6) 19: 488.

Glenea hachijonis Matsumura et Matsushita, 1933, Ins, Matsu. 7: 110.

Glenea (Glenea) chlorospila : Mitono, 1940, Cat. Col. Japonic. 8: 207.

Glenea chlorospila var. humerolineata: Hayashi, 1956, Bull. Osaka Mun. Mus. Nat. Hist. 9: 19.

Glenea chlorospila m. hayashii Ohbayashi, 1963, Fragmenta Col. 3: 12.

Specimens examined : 1 ㅇ, Ogora, 23. VII. 1975, H. Makihara leg. ;

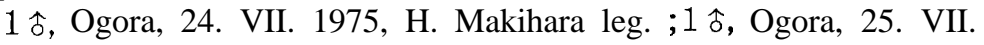
1975, H. Makihara leg. ; $1 \hat{\delta}$, Ogora, 23-25. VII. 1975, H. Makihara 
leg.

Distribution: Shikoku, Kyushu, Izu Isls., Tanegashima Is., Yakushima Is., Kuroshima Is., Kuchinoshima Is., Nakanoshima Is., Takara jima Is., Kikai jima Is., Amami-Oshima Is., Tokunoshima Is., Okinoerabujima Is. and Okinawa Is.

Note: New record. One example was collected by the Malaise trap.

\section{References}

Bates, H. W., 1873. On the Longicorn Coleoptera of Japan. Ann. Mag. Nat. Hist., (4) 12: 148-156, 193-201, 308-318, 380-390.

Breuning, S., 1955. Nouveaux Lamiaires du Museum National d'Histoire Naturelle (Col., Cerambycidae). Bull. Soc. Ent. Fr., 60: 70-77.

Breuning, S. et Ohbayashi, K., 1964. Nouveaux Lamiaires du Japon (Col., Cerambycidae). Bull. Japan Ent. Ac., 1 (4): 15-18.

—_ et — 1966. Nouveaux Lamiaires du Japon (3 partie) (Col., Cerambycidae). ibid., 2 (6): 31-36.

__ et _—, 1967. Nouveaux Lamiaires du Japon (4 partie) (Col., Cerambycidae). ibid., 3 (2): 3-4.

Gahan, C. J., 1897. Notes on the Longicorn Genus Glenea, Newm., with Descriptions of New Species. Ann. Mag. Nat. Hist., (6) 19: 473-493.

Gressitt, J. L., 1951. Longicorn Beetles of China. Longicornia, 2: 1-667, 22 pls.

—, 1956. Insects of Micronesia (Col., Cerambycidae). Insects of Micronesia, 17 (2): 1-183.

Hayashi, M., 1955. Coloured illustrations of the insects of Japan, Coleoptera, Cerambycidae : 132-190, 19 pls. (In Japanese).

—, 1956. Entomological results from the scientific survey of the Tokara Islands 5. Col. : Cerambycidae. Bull. Osaka Mun. Mus. Nat. Hist., 9: 11-22.

-_., 1960. The Cerambycidae in Ryukyu Islands. Ent. Rev. Japan, 11 (1): 21-29. (In Japanese).

_, 1961. The Cerambycidae from Amami-Oshima Islands 1. Ent. Rev. Japan, 13 (2): 35-46.

--, 1961. The Cerambycidae of Japan 4. Ent. Rev. Japan, 13 (2): 53-60. (In Japanese).

— , 1961. Une Nouvelle Espèce de Rhodopina du Nord des Iles Ryukyu (Col., Ceramby., Lamiinae). Bull. Osaka Mun. Mus. Nat. Hist., 13: 67-70.

__, 1962. The Cerambycidae from Amami-Oshima Islands 2. Ent. Rev. Japan, 14 (1) : 8-18.

__ 1963. Studies on Cerambycidae from Japan and its Adjacent Regions 14. Ent. Rev. Japan, 15 (2): 56-58. (In Japanese).

_ 1963. The Cerambycidae of Ryukyu Islands 3. Ent. Rev. Japan, 16 (1): $10-16$.

—, 1969. Studies on Cerambycidae from Japan and its Adjacent Regions 17. 
Ent. Rev. Japan, 21 (2): 61-66.

- 1971. Studies on Cerambycidae from Japan and its Adjacent Regions 18. Ent. Rev. Japan, 23 (1) : 1-18.

- 1972. Studies on Cerambycidae from Japan and its Adjacent Regions 19. Ent. Rev. Japan, 24 (1/2): 25-41.

Ito, J. et Moriya, K., 1975. The Cerambycidae of Kuchinoerabujima Island. Gekkan-Mushi, 50 : 24-27. (In Japanese).

Kojima, K. et Hayashi, M., 1969. Insect's life in Japan. 1: 1-295. 56 pls. (In Japanese).

Kusama, K., 1973. The list of biology and distribution of Cerambycidae in Japan. New insect collecting 3, Suppl.: 1-159. (In Japanese).

Makihara, H., 1970. Studies on the distribution of Cerambycid-beetles from the Ryukyu Archipelago in comparison with the geographical history of the islands. Leben, Biol. Soc. Kagoshima Univ. 9: 2-59. (In Japanese).

- 1970. A list of Cerambycid-beetles from the Ryukyu Archipelago. Leben, Biol. Soc. Kagoshima Univ. 9: 60-85. (In Japanese).

—, 1973. Cerambycid fauna of Kikaijima Island. Tsukushi no Kontyu, 14 (2): 3316. (In Japanese).

- 1974. The Cerambycidae of Tarama Island. Pulex, 55: 226. (In Japanese).

Matsushita, M., 1933. Beiträg zur Kenntnis der Cerambyciden des japanischen Reichs. Jour. Fac. Agr. Hokkaido Imp. Univ., 34 (2): 157-445. 5 pls.

Ohbayashi, K., 1961. New Cerambycidae from Japan 6. Ent. Rev. Japan, 13 (1) : 16-20.

- 1.263. Iconographia Insectorum Japonicorum colour natural edita. 2: 267-318. 26 pls. (In Japanese).

Ohbayashi, N., 1964. A list of Cerambycidae from the Tokara Amami Isls. Ehime Univ. 1: 37-43. 1 pl. (In Japanese).

Pascoe, F. P., 1858. Descriptions of new genera and species of asiatic Longicorn Coleoptera, part 3. Trans. Ent. Soc. London, (2) 4: 236-266. 2 pls.

Sakamoto, K. et Shima, H., 1965. The Cerambycidae of Kagoshima Prefecture. Satsuma, 13 (3): 70-165. 2 pls. (In Japanese).

Samuelson, G. A., 1965. The Cerambycidae of the Ryukyu Archipelago 2. Lamiinae. Pac. Ins., 7 (1): 82-130.

Samuelson, G. A, et Gressitt, J. L., 1965. The Cerambycidae of the Ryukyu Archipelago 1. Pac. Ins., 7 (1): 47-81.

White, A., 1856. Catalogue of Coleopterous insects in the collection of British Museum. part 8. Longicornia 2: 175-412. 10 pls.

Yokoyama, H., 1972. The Cerambycidae from Ryukyu and Satsunan Islands 2. Ent. Rev. Japan, 23 (2): 93-101. 